\author{
Asian Journal of \\ Medical and Biological Research \\ ISSN 2411-4472 (Print) 2412-5571 (Online) \\ www.ebupress.com/journal/ajmbr
}

\title{
Article \\ Ethnomedicinal survey of plants used by the folk medicinal practitioner (FMP) in the Jamalpur sadar Upazila, Jamalpur district, Bangladesh
}

Tanvir Ahamed ${ }^{1}$, Koushik Mondal ${ }^{2}$, Muhammad Ismail Khan ${ }^{2}$, Tahmina Nasrin Munni ${ }^{3}$, Tanziba Alam $^{4}$ and Rashedul Islam ${ }^{2,5^{*}}$

${ }^{1}$ Department of Biotechnology and Genetic Engineering, Bangabandhu Sheikh Mujibur Rahman Science and Technology University, Gopalganj-8100 Bangladesh

${ }^{2}$ Department of Biotechnology and Genetic Engineering, Jahangirnagar University, Savar, Dhaka-1342, Bangladesh

${ }^{3}$ Department of Pharmacy, University of Development Alternative, Dhanmondi, Dhaka-1209, Bangladesh

${ }^{4}$ Department of Biochemistry and Molecular Biology, Jahangirnagar University, Savar, Dhaka-1342, Bangladesh

${ }^{5}$ Quality Control Department, Eskayef Pharmaceuticals Bangladesh Ltd.

*Corresponding author: Rashedul Islam, Department of Biotechnology and Genetic Engineering, Jahangirnagar University, Savar, Dhaka-1342, Bangladesh. Phone: +8801930286146; E-mail: rashedbgeju@ gmail.com

Received: 07 December 2018/Accepted: 24 December 2018/ Published: 30 December 2018

\begin{abstract}
The Folk medicinal practitioner (FMP) or Kabiraj plays a key role to provide health support mainly to village people. They are mainly dependent on the pants parts available around them and many modern medicines are being synthesized by extracting the active chemicals from plants. The main objective of this study is to document the plants used by the FMPs of two villages of Jamalpur sadar upazila. For this study, we conducted a survey based on semi structured method. We found they use mainly 31 plants belonging to 25 families. The part mostly used is leave (31.75\%) and the least used is the flower (6.34\%). It is found that almost 18 types of diseases are being cured by their formulation. This study also suggested that, the FMPs treat many common disorder like gastro intestinal disorder, Respiratory tract infection, diabetes, Skin disorder etc. and also various complicated disorder such as debility, anemia, neural disorder etc. This study may be helpful to create scientific view about the plants used by the FMPs of Jamalpur sadar upazila and these plants might be used to synthesize drug molecule of interest.
\end{abstract}

Keywords: FMPs; medicinal plants; folk medicine; kabiraj

\section{Introduction}

Folk medicinal practice is very common in Bangladesh. There might be found at least one folk medicinal practitioner in (FMP) also known Kaviraj in every village or community in Bangladesh. Folk medicinal practice is also common in other parts of the world. In addition to Indian sub-continent countries like India, Pakistan, Nepal, Sri Lanka and Bangladesh other countries like Turkey, China and Japan also their traditional folk medicines (Jannat et al., 2015; Rahmatullah et al., 2010a). Majority (80\%) of the people in developing countries rely on traditional medicines for the treatment of primary healthcare as medicinal plants are easily attainable and cheap too (Nyamanga et al., 2008; Sultana and Rahmatullah, 2016). Ethno-medicinal surveys have revealed that there are great variations among uses of herbal medicine in various cultural, indigenous and social groups (Lee et al., 2008). Therefore, documentation and archiving of knowledge of medicinal plants is considered as from top to bottom importance to support the discovery of drugs benefiting humankind as well as saving endangered plant species too (Dutta and Dutta, 2005). Several anti-cancer drugs for example camptothecin, ingenol-3-Oangelate, phenoxoidal and epipodophyllotoxin have been discovered through folk medicinal practice (Rao et al., 
2008). In 2015, Tu Youyou won Nobel Prize in medicine for discovery of antimalarial drug artemisinin which was initially as traditional medicine. Low income countries have more biodiversity which could be good source of medicines. A good number of ethno-medicinal surveys have been conducted in Bangladesh (Mollik et al., 2009; Rana et al., 2010 ) in last few years including Jamalpur district (Rahmatullah et al., 2010b; Jannat et al., 2015). The bone of the Ethno-medicinal researcher is the uniqueness of the plants used by the FMPs. Researcher may gain knowledge from the surveys of FMPs. For this, A few surveys of the ethno-medicine are not enough. To build a complete comprehensive database on medicinal plants of Bangladesh surveys had been conducting for several years. In addition to this, we conducted a survey among FMPs in two villages of Jamalpur district to reveal variations in uses of plants for the treatment of several diseases. In the two villages, there are four FMPs who practice on the folk medicine. Prior consent was made to visit them and to document the plants used by them to prepare Ethno-medicine.

\section{Materials and Methods}

\subsection{Study periods and area}

The present study was conducted in the two villages of the sadar upazila under the Jamalpur district of Mymensingh division; namely Sreepur and Fotepur from January to May, 2017.

\subsection{Sampling population}

The study was conducted in two villages of Jamalpur district under sadar upazila. In total, 3 FMPs were interviewed ages ranging from 50-70 years. All FMPs were men. Purpose of the visit and study was explained broadly. Additionally, it was also informed and consent was taken that any information gained from them will be disseminated in both national and international scientific platforms.

\subsection{Data collection}

Language of interviews was Bangla (spoken by all FMPs) following a semi-structured questionnaire. In this method, the FMPs took the interviewers on guided field-walks through areas from where they collected their medicinal plants, pointed out the plants and mentioned their local names, uses and method of use, formulations, diseases for which the formulations were used and dosages. Information was also collected on the season of plants collection, which plant parts used and whether combination of plants were used to treat any particular disease or if any single plant was used to treat multiple diseases. Data collected from one person were verified with others by asking the same questions.

\subsection{Data analysis}

Entire collected data were précised and inspected cautiously and documented. Afterward assortment of data, these were revised and notched. In conclusion, significant tables were prepared in accordance with the objectives of the study. Data were analyzed using the Microsoft excel 2007.

\section{Result}

\subsection{Medicinal plants used by the kabiraj}

A total 31 plants, distributed in the 25 families were found to be used by the kabiraj for the treatment of various diseases. These plants, Scientific and family name, used parts and controlled diseases are listed in the table. All the parts of plants are used by the kabiraj (Table 1).

Table 1. List of Medicinal plants used by the kabiraj of two villages of Jamalpur sadar upazila.

\begin{tabular}{|c|c|c|c|c|}
\hline Local name & Scientific name & Family name & Used parts & Controlled disease \\
\hline Lojjaboti & Mimosa pudica & Fabaceae & Whole plant & $\begin{array}{l}\text { Wounds, piles, insect bite, diabetes, } \\
\text { asthma, itching, high blood pressure, } \\
\text { diarrhea, kidney pain }\end{array}$ \\
\hline Amloki & $\begin{array}{l}\text { Phyllanthus emblical } \\
\text { Emblica officinalis }\end{array}$ & $\begin{array}{l}\text { Euphorbiaceae/ } \\
\text { Phyllanthaceae }\end{array}$ & Fruits, leaf & $\begin{array}{l}\text { Diabetes, hair fall, diarrhea, dysentery, } \\
\text { anemia, jaundice, indigestion, cold, cough }\end{array}$ \\
\hline Bohera & Terminalia belerica & Combretaceae & Fruit & $\begin{array}{l}\begin{array}{l}\text { Cough, cold, asthma, } \\
\text { diarrhea, } \\
\text { hypertension, cancer }\end{array}\end{array}$ \\
\hline Bashok & $\begin{array}{l}\text { Justicia adhatodal } \\
\text { Adhatoda vasica }\end{array}$ & Acanthaceae & $\begin{array}{l}\text { Leaf, Root, } \\
\text { Flower }\end{array}$ & $\begin{array}{l}\text { Cough, asthma, pain, indigestion, diabetes, } \\
\text { bronchitis, diarrhea, fever, wounds, } \\
\text { anorexia }\end{array}$ \\
\hline
\end{tabular}




\begin{tabular}{|c|c|c|c|c|}
\hline Local name & Scientific name & Family name & Used parts & Controlled disease \\
\hline $\mathrm{Nim}$ & Azadirachta indica & Meliaceae & $\begin{array}{l}\text { Leaf, root, } \\
\text { bark, seed }\end{array}$ & $\begin{array}{l}\text { Leprosy, eye disorders, bloody nose, } \\
\text { intestinal worms, stomach upset, skin } \\
\text { ulcers, fever, diabetes, gingivitis, itching, } \\
\text { eczema }\end{array}$ \\
\hline Durba & cynodon dactylon & Poaceae & Whole plant & $\begin{array}{l}\text { Acidity, diabetes, skin rash, cold, obesity, } \\
\text { piles, wounds, syphilis, diarrhea, blood } \\
\text { cancer }\end{array}$ \\
\hline Joba & $\begin{array}{l}\text { Hibiscus rosa- } \\
\text { sinensis }\end{array}$ & Malvaceae & Fower, leaves & $\begin{array}{l}\text { Hair loss, constipation, cold, fever, cancer, } \\
\text { hypertension, leucorrhea, nerve disease. }\end{array}$ \\
\hline Tit begun & Solanum indicum & Solanaceae & $\begin{array}{l}\text { Root, leaves, } \\
\text { fruit }\end{array}$ & $\begin{array}{l}\text { Asthma, fever, vomiting, diarrhea, } \\
\text { anorexia, cough, rheumatism, epilepsy, } \\
\text { itching }\end{array}$ \\
\hline Nishinda & Vitex negundo & $\begin{array}{l}\text { Verbenaceae/ } \\
\text { Lamiaceae }\end{array}$ & Leaves & $\begin{array}{l}\text { Diabetes, tumor, cancer, acne, eczema, } \\
\text { arthritis, headaceae, rheumatism, fever, } \\
\text { paralysis }\end{array}$ \\
\hline Jamal gota & Croton tiglium & Euphorbiaceae & Leaves, seed & Constipation, cold, itching \\
\hline Bel & Aegle marmelos & Rutaceae & $\begin{array}{l}\text { Fruit, leaf, } \\
\text { flower }\end{array}$ & $\begin{array}{l}\text { Dyspepsia, diarrhea, dysentery, vomiting, } \\
\text { diabetes, constipation, ulcer, skin disease }\end{array}$ \\
\hline Tetul & Tamarindus indica & Fabaceae & $\begin{array}{l}\text { Fruit, seed, } \\
\text { leaf }\end{array}$ & $\begin{array}{l}\text { Diabetes, indigestion, diarrhea, anorexia, } \\
\text { wounds, obesity, cancer }\end{array}$ \\
\hline Guikumra & Ipomoea paniculata & Convolvulaceae & Whole plant & Leucorrhea, menstruation, liver cirrhosis \\
\hline Jam & Syzygium cumini & Myrtaceae & $\begin{array}{l}\text { Fruit, seed, } \\
\text { leaf, bark }\end{array}$ & $\begin{array}{l}\text { Diabetes, diarrhea, bronchitis, asthma, } \\
\text { depression, ulcer, constipation }\end{array}$ \\
\hline Shimul & Bombax ceiba & Malvaceae & $\begin{array}{l}\text { Root, leaf, } \\
\text { flower, bark, } \\
\text { throns, resin }\end{array}$ & $\begin{array}{l}\text { Diarrhea, wound, burning, tumor, acne, } \\
\text { weakness, cold, cough }\end{array}$ \\
\hline Amm & Mangifera indica & Anacardiaceae & $\begin{array}{l}\text { Leaf, seed, } \\
\text { fruit, bark }\end{array}$ & $\begin{array}{l}\text { Neuralgia, constipation, paralysis, } \\
\text { bloating, gout, diarrhea }\end{array}$ \\
\hline Tulsi & $\begin{array}{l}\text { Ocimum tenuiflorum } \\
\text { (sanctum) }\end{array}$ & Lamiaceae & Whole plant & $\begin{array}{l}\text { Acne, cancer, diabetes, fever, headaches, } \\
\text { tuberculosis, oral disease }\end{array}$ \\
\hline Shial moti & Blumea lacera & Asteraceae & Whole plant & $\begin{array}{l}\text { Pain, worms, headache, pus filled wounds, } \\
\text { piles, mouth ulcers, fever }\end{array}$ \\
\hline Tukma & Hyptis suaveolens & Lamiaceae & Leaf, seed & $\begin{array}{l}\text { Rheumatism, eczema, boils, headaches, } \\
\text { constipation }\end{array}$ \\
\hline Ulotkombal & Abroma augustum & Sterculiaceae & $\begin{array}{l}\text { Bark, root, } \\
\text { leaf }\end{array}$ & $\begin{array}{l}\text { Bronchitis, diabetes, rheumatism, pain, } \\
\text { dysentery, weaknes }\end{array}$ \\
\hline Arokkolai & Cajanus cajan & Fabaceae & $\begin{array}{l}\text { pods, shoots, } \\
\text { leaves, root }\end{array}$ & $\begin{array}{l}\text { High blood pressure, anemia, obesity, } \\
\text { constipation, diarrhea, wounds, jaundice }\end{array}$ \\
\hline Koichguta & Abrus precatorius & Fabaceae & Seed & $\begin{array}{l}\text { Epithelioma, ulcers, hypertension, } \\
\text { nephritis, epilepsy, tetanus, cholera }\end{array}$ \\
\hline Bilaihungi & Tragia involvucrata & Euphorbiaceae & Leaf & $\begin{array}{l}\text { Hair hall, dandruff, arthritis, bursitis, } \\
\text { rheumatism, gout }\end{array}$ \\
\hline Ammguloncho & plumeria rubra & Apocynaceae & $\begin{array}{l}\text { Root, bark, } \\
\text { leaves }\end{array}$ & $\begin{array}{l}\text { Cholera, indigestion, ulcers, itching, fever, } \\
\text { rheumatism }\end{array}$ \\
\hline Makal & $\begin{array}{l}\text { Hodgsonia } \\
\text { heteroclita }\end{array}$ & Cucurbitaceae & Leaf and fruit & Wound healing, bacterial infection \\
\hline Gur roshun & Allium sativum & Amaryllidaceae & Bulb & $\begin{array}{l}\text { Cardiovascular diseases, hypertension, } \\
\text { cancer. }\end{array}$ \\
\hline Kharajora & Litsea glutinosa & Lauraceae & Leaf & $\begin{array}{l}\text { Fungal/ bacterial infections, hysteria, } \\
\text { diarrhea, dysentery. }\end{array}$ \\
\hline Ginger & Zingiber officinale & Zingiberaceae & Rhizome & $\begin{array}{l}\text { Dyspepsia, gastroparesis, constipation, } \\
\text { nauseaallergy, bowel disease, ulcer. }\end{array}$ \\
\hline Garlic & Allium sativum & Amaryllidaceae & Bulb & $\begin{array}{l}\text { Cardiovascular diseases, hypertension, } \\
\text { cancer. }\end{array}$ \\
\hline Kalomegh & $\begin{array}{l}\text { Andrographis } \\
\text { paniculata }\end{array}$ & Acanthaceae & Whole plants & $\begin{array}{l}\text { Respiratory diseases, HIV infection, } \\
\text { cancer. }\end{array}$ \\
\hline Shojna & Moringa oleifera & Moringaceae & Leaf & Fever, bronchitis, skin diseases, diarrhea. \\
\hline
\end{tabular}




\subsection{Parts of plant used by kabiraj}

Among these the leaf, fruit, whole plant, root, flower, bark, seed, pod, resin, bulb and rhizome are mostly used. Leaf is being highly used almost $31.75 \%$ followed by the root $(12.70 \%)$, fruit $(11.11 \%)$, seed $(11.11 \%)$, bark (9.52\%), whole plant (9.52\%), stem (7.94\%) and flower (6.34\%) (Figure 1).

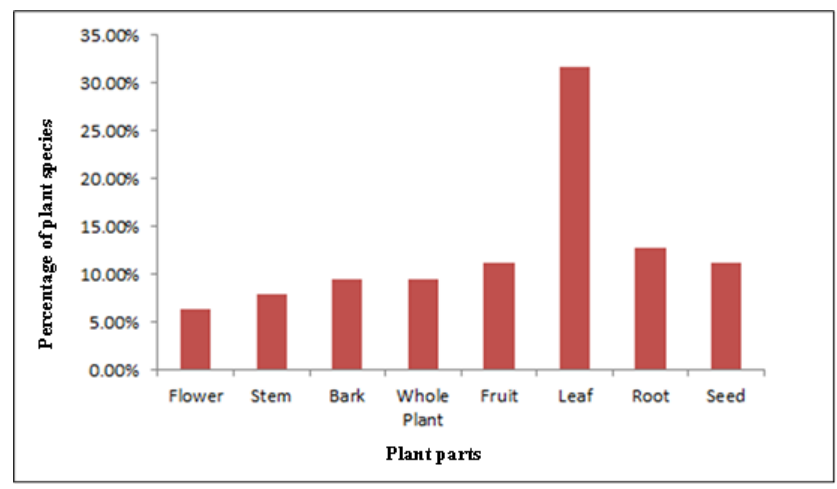

Figure 1. Plants parts distribution in disease treatment and formulation used by FMP.

\subsection{Use of ethnomedicine in various diseases}

In our study, it was observed that the various plant parts formulations are used to treat 18 types of diseases. Plant parts are used for the treatment of mostly gastrointestinal disorder and followed by the skin disorder, respiratory tract disorder, diabetes and fever. Most of the folk medicines are prepared by boiling the plants parts and along with crushing and mixing with water (Figure 2).

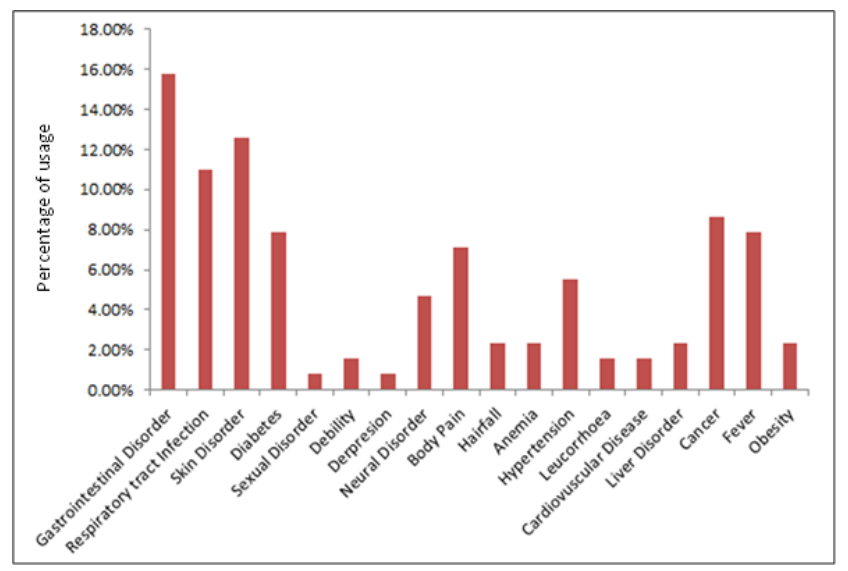

Figure 2. Percentage of use of ethnomedicine in various diseases.

\section{Discussion}

Although moderns doctors treat the treatments of the kabiraj as fraud and useless but many scientific reports validates use of many plants by the kabiraj. Many of the medicinal plants are now being used for the new drug formulation. Many plants resemble with the plants used by the kabiraj of other places for the treatment of same disease. For example Cinnamomum verum is used for diabetes by FMPs of station Purbo Para village, Jamalpur district (Rahmatullah et al., 2010a; Khan et al., 2015).This present study reflect 31 species of different plants which is used as medicinal purposes; several study has similar findings with our research (Jannat et al., 2015; Rahmatullah et al., 2010b). A similar study also shown that, several number of aquatic plant was also belongs to Bangladesh Agricultural University (BAU) campus (Islam et al., 2017). Leaf is highly preferred as medicine to the community as leaf is highly easier to collect, storing and processing too. Maximum numbers of administrations are oral. This is usually called the internal administration and it is highly preferred by the rural community as they believe that entering medicine into body is highly effective (Uddin et al., 2013). Due to the modernization, people lack their interest on the folk medicine. Also lack of the proper documentation of the formulation and plant used by the kabiraj, these folk medicines are losing their glorious history. The number of 
kabiraj is decreasing as the incomes of these kabiraj are so limited. Proper documentation of these folk medicines could help to synthesize new drug molecule for many diseases.

\section{Conclusions}

The present observations revealed that the study area is rich in wild plants having ethno-botanical value. It can be seen from the observations made that there are a wide variety of plants for every day common ailments and diseases. The plants about which information have been generated so far should be conserved, the information/database so far generated should also be conserved and utilized.

\section{Conflict of interest}

None to declare.

\section{References}

Dutta BK and PK Dutta, 2005. Potential of ethno-botanical studies in North East India: an overview. Indian J. Trad. Know., 4: 7-14.

Islam MD, SM Rahmatullah, M Ahmed, AA Asif, A Satter, B Sarker, A Hossain and S Mojumder, 2017. Aquatic weeds diversity of Bangladesh Agricultural University Campus, Mymensingh, Bangladesh. AsianAustra. J. Biosci. Biotech., 2: 181-192.

Jannat K, M Akter, S Sharmin, U Rukaiya, M Afrin, PR Das, MT Islam and M Rahmatullah, 2015. Ethnomedicinal practices of folk medicinal practitioners in two villages of Jamalpur district, Bangladesh. World J. Pharm. Pharmaceut. Sci, 4: 201-211.

Khan MA, MK Islam, MA Siraj, S Saha, AK Barman, K Awang, MM Rahman, JA Shilpi, R Jahan, E Islam, M Rahmatullah, 2015. Ethno-medicinal survey of various communities residing in Garo hills of Durgapur, Bangladesh. J. Ethnobiol. Ethnomed., 11: 44.

Lee S, C Xiao and S Pei, 2008. Ethnobotanical survey of medicinal plants at periodic markets of Honghe prefecture in Yunnan province, SW China. J. Ethnopharm., 117: 362-377.

Mollik AH, T Islam, A Khatun, D Nasrin, R Jahan and M Rahmatullah, 2009. Medicinal plants used against gastrointestinal tract disorders by traditional medicinal practitioners of Bangladesh. Planta Medica, 75: PD57.

Nyamanga PA, C Suda and J Aagaard-Hansen, 2008. The socio-cultural context and practical implications of ethnoveterinary medical pluralism in western Kenya. Agri. Human Val., 25: 513-527.

Rahmatullah M, D Ferdausi, A Mollik, R Jahan, MH Chowdhury and WM Haque, 2010. A survey of medicinal plants used by Kavirajes of Chalna area, Khulna district, Bangladesh. African J. Trad. Compl. Alt. Med., 7: 91-97.

Rahmatullah M, MA Rahman, MZ Haque, MAH Mollik, ZUMEU Miajee, R Begum, 2010. A survey of medicinal plants used by folk medicinal practitioners of Station Purbo Para village of Jamalpur Sadar Upazila in Jamalpur district, Bangladesh. Am. Eur. J. Sustain. Agr., 4: 122-35.

Rana MP, MSI Sohel, S Akhter and MJ Islam, 2010. Ethno-medicinal plants use by the Manipuri tribal community in Bangladesh. J. Forestry Res., 21: 85-92.

Rao GV, S Kumar, M Islam and SE Mansour, 2008. Folk medicines for anticancer therapy-a current status. Cancer Therapy, 6: 913-922.

Sultana A and M Rahmatullah, 2016. A critical analysis of some medicinal plants used by a folk medicinal practitioner in Savar, Dhaka district, Bangladesh. World J. Pharm. Pharmaceut. Sci., 5: 2157-2166.

Uddin SB, RS Ratna and MO Faruque, 2013. Ethnobotanical study on medicinal plants of Rakhaing indigenous community of Cox's Bazar district of Bangladesh. J. Pharmacog. Phytochem., 2: 164-174. 